\title{
Does corporate governance affect accounting conservatism? Empirical evidence in the French context
}

\author{
Anis Jarboui \\ Associated Professor, Higher Institute of Business Administration, ISAAS \\ *Corresponding authorE-mail: anisjarboui@yahoo.fr
}

\begin{abstract}
In the present study, we investigate the relationship between corporate governance (Boards of directors, Ownership) and accounting conservatism. We examine our model in the context of French firms over the period 2007-2011. We predict that an effective set of corporate governance mechanisms is positively related to a higher level of accounting conservatism. Empirical tests show that accounting conservatism depends mainly on the effectiveness of the board, the management shareholding, and the audit quality.
\end{abstract}

Keywords: Board of directors, corporate governance, accounting conservatism.

\section{Introduction}

The recent financial scandals in companies such as Enron, Parmalat and Vivendi Universal has broken the confidence of the investors and raised the question of the reliability of the financial statements on which a large part of capital market activities is based. According to [35] the accounting standards played their role in the crisis of confidence of the investors and distinguish the phenomenon of opportunism, by virtue of which the principle of conservatism was abandoned in favor of the principle of "fair view ". [37] note that corporate scandals in American companies such as Enron and WorldCom served as a catalyst for the passage of the Sarbanes-Oxley Act. The requirements of the Sarbanes-Oxley Act aim to "protect investors by improving the accuracy and reliability of corporate disclosures and to restore investors' confidence in the integrity of firms' financial statements". [37] present evidence that firms on average are more conservative in their financial reporting after Sarbanes-Oxley Act.

The principle of accounting conservatism influences the financial statements of the company, which can lead to a discrepancy between the financial figure and the real market value of the firm [18]. In this way the presence of such a principle implies a dominance of historical figures by the effect of this accounting integration delay. Moreover, the principle of accounting conservatism is otherwise said asymmetric recognition of gains and losses. In fact, this principle does not mean that it is necessary to integrate the gains when they occur. The lower bound of the value of assets of a company is one of the consequences of this asymmetry.

[6] explains that conservatism implies that accountants should report the lowest values of assets and revenues and the highest values of liabilities and expenses. Accounting conservatism is interpreted as the accountants' tendency to require a higher degree of verification to recognize good news as gains rather than to recognize bad news as losses. Thus, unrealized losses are recognized earlier than unrealized gains [4]. Similarly, [20] define accounting conservatism as being a criterion of selection between several accounting principles which entail the minimization of profits because of a delay to take into account revenue; fast recognition of expenses; the lowest evaluation of assets and overstatement of liabilities. Accounting conservatism is defined by [44] as;"the differential verifiability required for recognition of profits versus losses. Its extreme form is the traditional conservatism adage: 'anticipate no profit, but anticipate losses". [34] examined the level of accounting conservatism across eight European countries (United Kingdom, Germany, France, Switzerland, the Netherlands, Italy, Spain and Belgium). The definitions of conservatism used were, on the one hand, the definition by [15] which reflects balance sheet conservatism. On the other hand, they used the one proposed by [4] which measures earnings conservatism. [34] provide evidence on the existence of both balance sheet and earnings conservatism in Europe. The tests show also that code-law-based countries are more balance-sheet conservative.

In this paper, we study the influence of corporate governance mechanisms on conservatism in financial statements published by French companies. The corporate governance mechanisms studied here are: The board of directors and the ownership structure. The present work presents a double interest: 
First, it allows studying conservatism in a context whose accounting culture and institutional characteristics are different from those of Anglo-Saxon countries where such accounting properties were analyzed ([5] [1] [33] [34]; and [3]). [7] highlights that French and German companies have higher levels of conservatism than American companies. Further, the examination of the trend of accounting conservatism sheds light on the properties of financial statements of French firms. Second, the measure of conservatism proposed in this study is different from the classical measures used in most of the studies which do not take into account all the aspects of the conservatism in financial statements.

The rest of paper is organized as follows. Section 2 "Literature review and hypothesis Development "highlights the link between corporate governance mechanisms studied and accounting conservatism and presents the hypothesis of the study. Section 3 provides the methodological approach, the empirical model and the definitions of the variables used in this study. Section 4 presents the statistical results, and Section 5 summarizes and concludes the study.

\section{Literature review and hypothesis development}

The structure of the board of directors has a considerable influence on the publication of credible and pertinent financial information [30]. The Board's members have to meet periodically with the accounting managers and the external auditors to revise the financial statements of the company, the procedures of audit as well as the procedures of internal control.

Empirical studies show that there is a significant positive relationship between accounting conservatism and the independence of the board of directors of the management [1] and [5]. This proves that boards with higher power of control may supply financial information elaborated with more conservatism. [1] conclude that conservatism is a potentially useful tool for directors especially outside directors in fulfilling their role of ratifying and monitoring key decisions. They suggest that "because stronger boards are likely to be more proficient at efficient contracting and understand the benefits of conservatism they are likely to demand more conservative accounting. On the other hand, boards dominated by insiders or boards with weak monitoring incentives are likely to provide managers with a greater opportunity to use aggressive accounting".

[10] concluded that the board size, its characteristics, and its composition influence the efficiency of its roles. [25] noted, as the number of directors grows it is more difficult to manage and to assure the coordination; the size of the board of directors is negatively associated with the ability of the board of directors to work effectively.

[13] point out that the existence of a leader within the board who is different from the Chief Executive Officer (CEO) could significantly help the directors to prevent the difficulties as well as to act in case of difficulties. The separation between the functions of CEO and chairman of the board strengthens consequently, the capacity of control of the board of directors and its independence of the management. It is in this sense that [41] underlines that the existence of a dominant personality, when both functions are combined, could prevent the implementation of mechanisms which could restrict the latitude of the CEO. If the separation between the functions strengthens the efficiency of control of the board, we could expect to find a significant relationship between conservatism and the structure of the board. [33] suppose and confirm on a sample of Spanish companies over the period 1997-2002, that companies, in which the CEO involvement in board decisions is low, have a higher level of conservatism. Several empirical studies have found a negative effect of this combination of functions CEO and Chairman of the process of establishing financial statement. Specifically, [13] found that companies where the CEO is also Chairman of the board were more likely to be included to violate the generally accepted accounting principles, particularly in the case of companies that do not have an audit committee. The influence of the CEO is measured by a composite measure including: the size, the proportion of the independent directors, the separation between the functions of the CEO and chairman.

Apart from the characteristics of the board of directors which are significant in influencing the level of accounting conservatism, the examination of the literature shows that the ownership structure also has an impact on accounting conservatism [1] [32] and [19]. A large number of external shareholders are often members of the board or have representatives in the board of directors. The fact of being a member of the board gives these investors the opportunity to check the process of financial reporting [30]. [30] confirms that the large presence of external shareholders decreases significantly accounting manipulations. Similarly, [24] and [42] advanced that large external shareholders reinforce the role of control of the board and could be assumed as a tool which prevent managers from earning management. The most shareholders typically exercise a degree of influence and control over the company. [39] stated that the concentration of capital increased effectiveness of control frameworks by shareholders. In the same vein, [12] have argued that the existence of such shareholders provides a control mechanism that can prevent managers'performance. However, [3] argue that the existence of controlling shareholders negatively affects the relevance of financial information. [1] who focused on the study of conservatism on a sample of English companies prove that there is a significant positive relationship between the level of conservatism and outside directors' participation in the capital. In fact, the voting power of active institutional investors allows them to influence the control systems in enterprises [40]. They are regarded as active because to put pressure on management to manage and lead in accordance with the interests 
of shareholders, or even cause changes in control systems and incentives. [18] note that institutional investors who require the publication of financial statement in due timing within regular financial term. [1] show that there is a significant negative relationship between the measures of conservatism and the participation of institutional investors. The authors explain that they are a control mechanism that can replace the control board. However, institutional investors can use their power to influence the leaders and bring them to protect their own interests at the expense of other investors [1].

According to the agency theory, large firms find it more difficult to control the behavior of leaders because of the importance of agency to manage conflicts. Therefore, incentives for the establishment of additional control mechanisms are higher in large companies. Studies developed in the context of the agency theory have often used the size of the firm as a "proxy" of the intensity of agency conflicts variable and argued that the large-size companies are likely to use various control mechanisms to control the behavior of leaders [41].

According to [23] the manager's possession of significant property percentage allows them to bring their commitment and be more attentive to the consequences of their actions on their wealth. They also state that if the leader has a certain amount of capital, the interest and the performance quality of financial reporting will increase. However, [30] noted a positive correlation between the share capital of the leader and earning management.

[34] note that the purpose of the Sarbanes Oxley act is to "protect investors by improving the accuracy and reliability of corporate disclosures" that's why, Sarbanes Oxley act requires to CEOs and CFOs of all exchange-listed firms to certify the "material accuracy and completeness of the financial statements." One implication of this requirement is that $\mathrm{CEO} / \mathrm{CFOs}$ have greater incentives to avoid using their discretion to overstate earnings and to be more conservative when faced with uncertainty and increased legal liability [45]. [35] document empirically an increase in the level of conservatism after the publication of the Sarbanes Oxley act. Further, [33] estimate the efficiency of corporate governance using a composite measure that incorporates the level of antitakeover protection and the level of CEO involvement in the decisions of the board of directors. They show, on a sample of US firms that conditional conservatism is significantly higher for firms with low antitakeover protection and low CEO involvement in board decisions. They conclude that stronger governance leads to more conservative accounting choices.

The foregoing discussion suggests the following hypothesis: an effective set of corporate governance mechanisms is positively related to higher level of accounting conservatism.

\section{Research design}

In this section, the methodology used for the empirical part of this research is presented and explained. The first part will introduce the type of research. Then the research model is explained. Finally, the data sample used for this research is presented.

\subsection{Measures of accounting conservatism}

The level of accounting conservatism constitutes the dependent variable. Like [20], we argue that [4] stimulated considerable research in accounting conservatism and his proposed measure of accounting conservatism was widely used in the empirical literature. The [4] measure of conservatism reports a single dimension of conservatism in income statement but is not taking into account conservatism in balance sheet statements of an entity, which constitutes a limitation of the previous studies.

Another limitation underlined by [43] is that it ignores the effects of conservatism prior to the estimation period and thus is not reflecting total conservatism. [28] propose a measure (C-Score) that can reflect the timing of conservatism changes and the variation of conservatism across firms within an industry. The authors empirically test and confirm the efficiency of C-Score as a measure of accounting conservatism.

[2] and [28] draw on the [4] measure of asymmetric timeliness to estimate a firm-year measure of conservatism. The model of [4] can be written as:

$$
\mathrm{Xi}, \mathrm{t} / \mathrm{Pi}, \mathrm{t}-1=\beta 0+\beta 1[\mathrm{Dit}]+\beta 2[\mathrm{Rit}]+\beta 3[\mathrm{Rit} \mathrm{Dit}]+\varepsilon \mathrm{i}, \mathrm{t}
$$

Where $\mathrm{X}$ i,t is the earnings per share for firm $\mathrm{i}$ in fiscal year $\mathrm{t}, \mathrm{Pi}, \mathrm{t}-1$ is the price per share at the beginning of the fiscal year, $\mathrm{R}$ it is the return on the firm $\mathrm{i}$ over the period 9 months before fiscal year-end to three months after fiscal yearend $t$, Dit is a dummy variable equal to 1 when $\mathrm{Rit}<0$ and equal to 0 otherwise and $\varepsilon i, t$ is the residual. The good news timeliness measure is $\beta 2$. The measure of incremental timeliness for bad news over good news, or conservatism, is $\beta 3$ and the total bad news timeliness is $\beta 2+\beta 3$.

The theory of conservatism in [44] suggests that conservatism varies with four factors: contracts (including debt and compensation contracts), litigation, taxation and regulation. Considerable research has documented the role of debt covenants and conservative financial accounting in addressing agency conflicts between lenders and borrowers [44] 
[22] [19] and [48]. Using a sample of over 5.000 debt issues, [40] test whether firms with more extensive use of covenants in their public debt contracts exhibit timelier recognition of economic losses in accounting earnings. [40] explains that covenants govern the transfer of decision-making and control rights from shareholders to bondholders when a company approaches financial distress and thereby limit managers' abilities to expropriate bondholder wealth. The author documents that covenants are expected to constrain managerial opportunism only if financial statements are prepared with a high level of conservatism. [40] supposes and proves that reliance on covenants in public debt contracts is positively associated with the degree of accounting conservatism.

[28] introduced in the Basu model the following variables: the market-to-book ratio; firm size; and firm leverage in order to generate C-Score, which estimates the level of conservatism. [28] suppose and find that conservatism is a linear function of the Market-to-Book Ratio, size and leverage. The specifications of C-Score are:

$$
\text { C-SCORE } \mathrm{i}, \mathrm{t}=\lambda 0+\lambda 1[\operatorname{SIZE~i,t]}+\lambda 2[(\mathrm{M} / \mathrm{B}) \mathrm{i}, \mathrm{t}]+\lambda 3[\mathrm{LEV} \mathrm{i}, \mathrm{t}]+\varepsilon \mathrm{i}, \mathrm{t}
$$

Where

SIZE: is the natural log of market value of equity

$\mathrm{M} / \mathrm{B}$ : the market-to-book ratio

LEV: $L$ is leverage, defined as long term and short term debt deflated by market value of equity

Empirical estimators of $\lambda \mathrm{i}, \mathrm{i}=0$ to 3 , are constant across firms, but they vary over time since they are estimated from annual cross-sectional regressions. C-Score is the firm-year measure of conservatism, or incremental bad news timeliness. The substitution of $\beta 3$ with $\mathrm{C}$-Score in equation 1 , ends in the following equation:

$$
\mathrm{Xi,t} / \mathrm{Pi}, \mathrm{t}-1=\beta 0+\beta 1[\mathrm{Di}, \mathrm{t}]+\beta 2[\mathrm{Ri}, \mathrm{t}]+\operatorname{Dit} \mathrm{R} \mathrm{i}, \mathrm{t}[\lambda 0+\lambda 1(\mathrm{SIZE}) \mathrm{i}, \mathrm{t}+\lambda 2(\mathrm{MB}) \mathrm{i}, \mathrm{t}+\lambda 3(\mathrm{LEVi}, \mathrm{t})]+\varepsilon \mathrm{i}, \mathrm{t}
$$

To estimate the level of conservatism concerning each company, we adopt the following approach [18]: we begin by estimating $\lambda \mathrm{i}, \mathrm{i}=0$ to 3 in equation 3 , then we introduce the estimated parameters in the equation of $\mathrm{C}$-Score.

\subsection{Models and variables}

To study the relationship between accounting conservatism and corporate governance we use the following model which allows to testing the influence of independent directors, the leadership structure of the board and its size, the institutional ownership, and the management ownership. We include each of the control variables discussed above (Audit, litigation and firm size). Because our tests rely on panel data, standard errors may be correlated within years and across time by firm. Thus, unless otherwise noted, in this and all subsequent estimations we either cluster our standard errors by firm and year or include firm fixed effects.

Model.1: Model with delayed variable C-score

C-SCORE i,t $=\beta 0+\beta 1($ C-score $) i, t-1+\beta 2$ Insdiri, $t+\beta 3$ CF i,t $+\beta 4$ BoardSize $i, t+\beta 5$ IInsti,t $+\beta 6$ ManOnw i,t $+\beta 7$ Audit $i, t+\beta 8$ Litigation $i, t+\beta 9$ Size $\varepsilon i, t$

Model 2: Model without delayed variable C-score

C-SCORE i,t $=\beta 0++\beta 1$ Insdiri,t $+\beta 2$ CF i,t $+\beta 3$ BoardSize $i, t+\beta 4$ IInsti,t $+\beta 5$ ManOnw i,t $+\beta 6$ Audit i,t + $\beta 7$ Litigation $\mathrm{i}, \mathrm{t}+\beta 8$ Size $\varepsilon i, \mathrm{t}$

Main variables / Board of directors and ownership structure

1) C-Score $i, t-1$ is the level of conservatism of the previous year,

2) Insdi $i, t$ is the percentage of inside directors. A director is considered as inside when he exercises executive functions in the firm or in the group,

3) $\mathrm{CF}$ i,t is a dummy variable that equals 1 if the CEO is also the chairman of the board and 0 when there is separation between the position of Chaiman of the board and the CEO or when the board have a two-tier structure supervisory board / management board,

4) BoardSize $i, t$ is the size of the board of director is measured by the number of directors,

5) Inst $i, t$ the participation of institutional investors in the capital,

6) ManOnw i,t : is the total common shares held by managers divided by the total common shares outstanding (Managerial ownership)

Control variables:Audit, litigation and firm size [47] document the role of the auditor as an efficient control mechanism and a guarantee of the credibility of the information. Indeed, several empirical studies document that the choice of the auditors is one of the best substitutes of certain mechanisms of governance [15] [11] and [36]. [44] explains that the risk of litigation encourages the accounting conservatism because litigation is much more likely when earnings and net assets are overstated, not understated. He points out that in most of the cases, firms are legally for the overestimation rather than the underestimation of profits and assets. In general, the risk of litigation signiflicantly influences the 
relationship between the auditor and his client, [46]. [15] show that the decisions of resignation or removal of auditors are significantly explained by the risk of litigation.

Similarly, we introduce a third control variable in our study, «the effect of the size of the firms ». Large company's face significant political costs which lead to translate the company's operations with more caution. [1] Ahmed show that there is a significant positive relationship between measures of the conservatism and the size of the company.

1) Audit it's a dummy variable taking the value 1 when the company in question is audited by at least one Big Four firms, and 0 otherwise.

2) Litigation it: like [15] we use a dummy variable which is equal to 1 if the company is a high-technology company and 0 otherwise to measure the risk of litigation.

3) Firm Size: The level of accounting conservatism has been controlled for by the size of the firm (total assets). Log transformation of size has been used to correct skewness in firm size.

\subsection{Sample Selection and data}

The tests have been made on all the industrial and commercial companies belonging to the SBF 120 index. The period of the study spreads out from the beginning of 2007 till the end of 2011 . We, have, therefore eliminated all the companies for which any data was missing during these five years as well as those belonging to sectors presenting a particular functioning (banks, leasing and insurance companies, or accounting practices requiring a specific treatment. The final sample consists of 252 firm- years observations from 2007 to 2011.

Table1: sample distribution across industries

\begin{tabular}{llll}
\hline & \multicolumn{3}{c}{ The Industry classification of the sample } \\
\hline Industry & SIC Codes & Firm & Percentage of total \\
\hline Petroleum & 13,29 & 17 & 6.74 \\
Consumer durable & $25,30,36,37,50,55,57$ & 32 & 12.69 \\
Basic Industry & $10,12,14,24,26,28,33$ & 50 & 19.84 \\
Food \& Tobacco & $1,2,9,20,21,54$ & 26 & 10.31 \\
Construction & $15,16,17,32,52$ & 23 & 9.12 \\
Capital Goods & $34,35,38$ & 27 & 10.71 \\
Transportation & $40,41,42,44,45,47$ & 15 & 5.95 \\
Textile and Trade & $22,23,31,51,53,56,59$ & 20 & 7.93 \\
Services & $72,73,75,76,80,82,87,89$ & 31 & 12.30 \\
Leisure & $27,58,70,78,79$ & 11 & 4.36 \\
\hline Total & & 252 & 100 \\
\hline
\end{tabular}

Three databases have been used (DIANE, WORLDSCOPE and DAFSA) to measure all the variables. The data of the corporate governance system are collected from the DAFSALIEN data-base. This stage of data collection was most difficult and required the construction of our own data-base (manually). The data of accounting conservatism are collected from the DIANE and WORLSCOPE database.

\section{Results: accounting conservatism in France and its relation with corporate governance mechanisms}

\subsection{Analysis of conservatism evolution over the period of 2007-2011}

Figure 1 reports the evolution of accounting conservatism in French financial statements over the period 2007-2011. The obtained results show that the level of the conservatism increased during observed years. Indeed, in 2007 average C-score is equal to 0.44 and 0.48 in 2011. [14] provide evidence that in French companies, good news has a delayed impact on earnings, as accountants only allow the effect of such news to be recognized gradually in the earnings measure. Conversely, bad news is reflected rapidly in earnings. The results of [14] confirm a general upward trend in the degree of conservatism of accounting earnings over the period from 1990 to 1999. The results show that the level of accounting conservatism increases after the mandatory adoption of IFRS. This trend is contradictory with down results generated by [39]. 


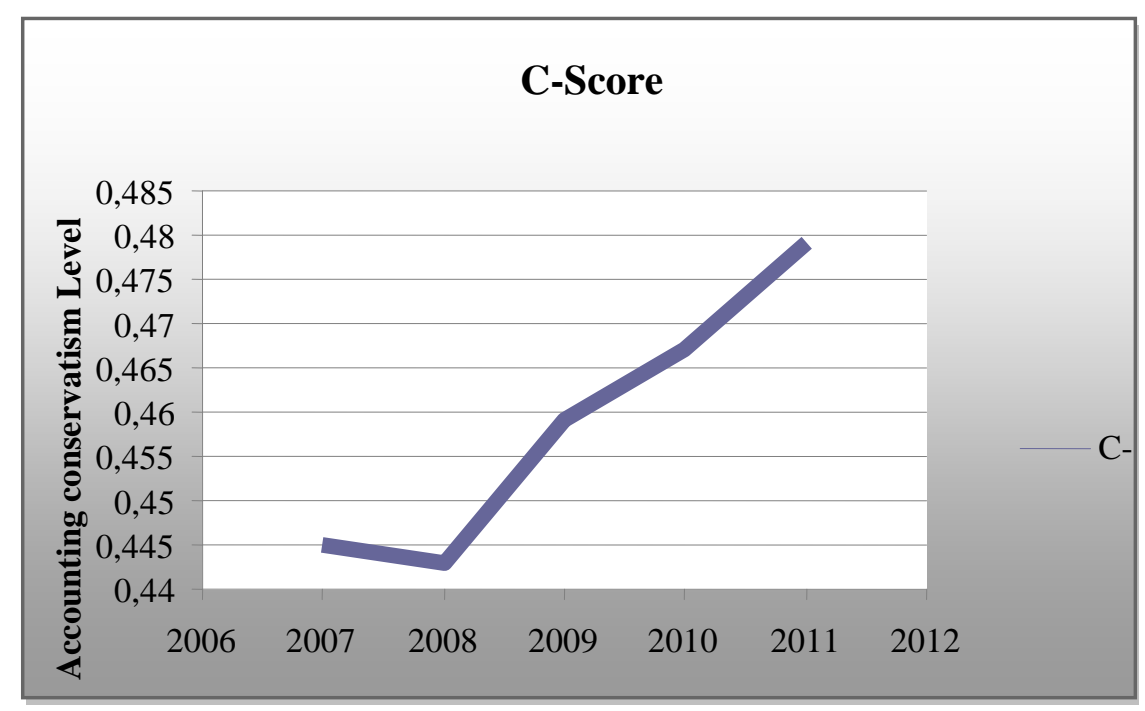

Fig. 1: Evolution of accounting conservatism 2007-2011

\subsection{Descriptive analysis and univariate analysis}

Table 2 shows the descriptive statistics of the primary variables. On average, the boards of directors of the companies of our sample consist of 8.32 members, $57.4 \%$ of them are internal directors. The analysis of ownership structure shows that institutional investors owns on average $33.12 \%$ in the capital of French firms and the average participation of the managers in the capital is $12.6 \%$. In $15.88 \%$ of the companies studied, the CEO is also the chairman of the board.

Table 2: descriptive statistics of all variables $(\mathrm{N}=252)$

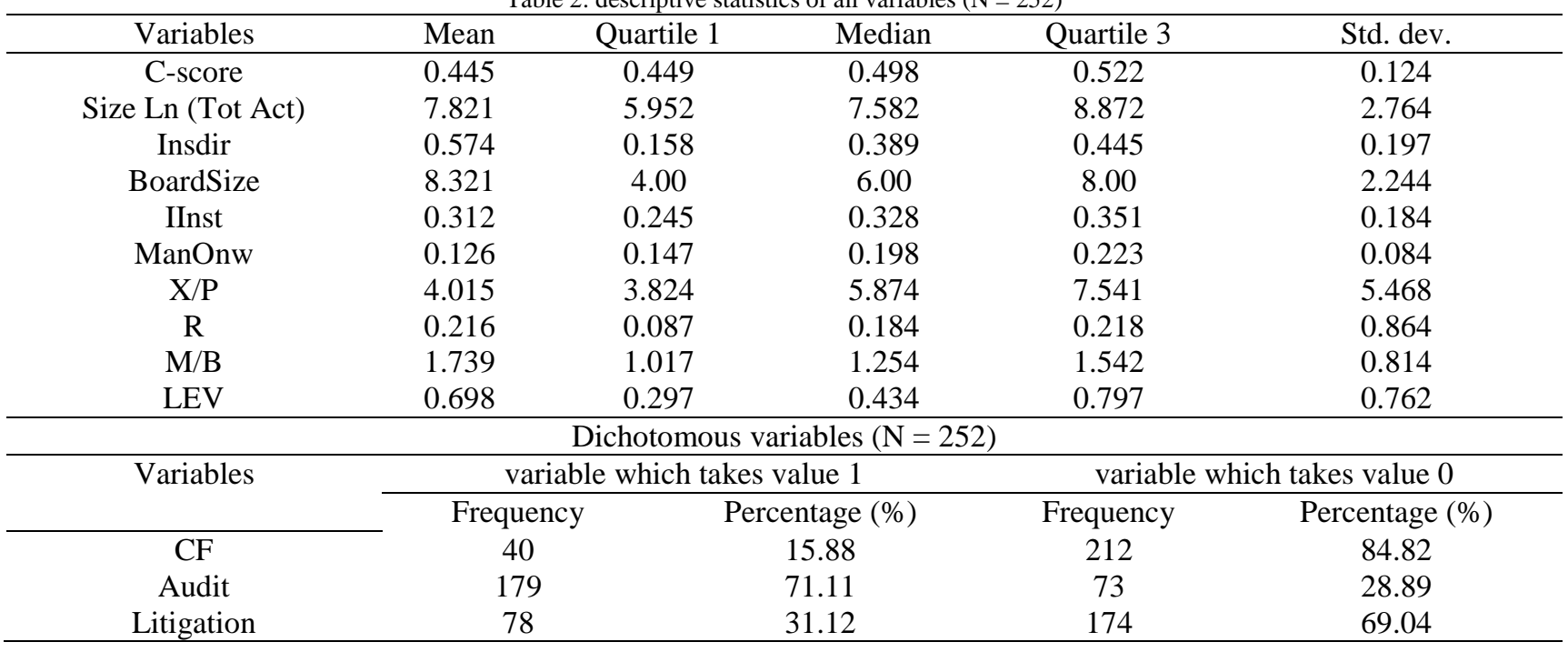

Table 3 shows the Pearson correlation coefficient matrix of the variables, thereby providing some basic analysis of the correlation between variables. Concerning the unvaried test, if dependent variable present two modalities, it is possible to realise the test of student for a null value of difference of the means of the dependants variables (H0 hypothesis) between two groups of firms (Table4 : Univariate Analysis). But if explicative variable is not normally distributed, it's necessary to make non-parametric test of the different means (This assumption was not checked in our sample. For this reason, we will resort to non-parametric tests). These tests are useful to know if the firms of the first group (which present a weak level of conservatism, C-Score is less than 0.494 (Group C-Score lowest)) present a significant difference with firms of the second group (high level of conservatism, C-Score is greater than 0.494 (Group C-Score highest) per explicative variables categories. 
Table 3: Pearson correlation coefficients between independent variables of model $(\mathrm{N}=252)$

\begin{tabular}{|c|c|c|c|c|c|c|c|c|}
\hline & C-score $_{\mathrm{t}-1}$ & Insdir & BoardSize & IInst & ManOnw & $\mathrm{CF}$ & Audit & Litigation \\
\hline C-score ${ }_{\mathrm{t}-1}$ & 1 & & & & & & & \\
\hline Insdir & $-0.423 * *$ & 1 & & & & & & \\
\hline BoardSize & $-0.225^{*}$ & $-0.271 * *$ & 1 & & & & & \\
\hline IInst & $0.421 * *$ & $0.412 * *$ & $-0.258 * *$ & 1 & & & & \\
\hline ManOnw & $-0.235^{* *}$ & $0.147 * *$ & $-0.285^{*}$ & $0.256^{* *}$ & 1 & & & \\
\hline $\mathrm{CF}$ & $0.142 *$ & $0.224 * *$ & $-0.156 *$ & 0.124 & 0.114 & 1 & & \\
\hline Audit & $0.411 * *$ & $-0.358 *$ & 0.074 & 0.098 & -0.047 & $-0.284 * *$ & 1 & \\
\hline Litigation & $-0.354 * *$ & $0.274 * *$ & $-0.114^{*}$ & $0.382 * *$ & $0.471 * *$ & 0.117 & -0.037 & 1 \\
\hline
\end{tabular}

Table 4 : Univariate analysis

\begin{tabular}{|c|c|c|c|c|c|}
\hline Variables & Groups & Mean/prop & t-test & Z-stat & $X^{2}$ test \\
\hline \multirow[t]{2}{*}{ Insdir } & C-Score lowest & Mean $=0.691$ & $\mathrm{t}=-5.904 * * *$ & $\mathrm{z}=-5.258 * * *$ & $\mathrm{n} / \mathrm{a}$ \\
\hline & C-Score highest & Mean $=0.458$ & $\mathrm{p}=(0.000)$ & $\mathrm{p}=(0.000)$ & $\mathrm{n} / \mathrm{a}$ \\
\hline \multirow[t]{2}{*}{ BoardSize } & C-Score lowest & Mean $=10.234$ & $\mathrm{t}=-2.340 * *$ & $\mathrm{z}=-5.753 * * *$ & $\mathrm{n} / \mathrm{a}$ \\
\hline & C-Score highest & Mean $=6.407$ & $\mathrm{p}=(0.020)$ & $\mathrm{p}=(0.000)$ & $\mathrm{n} / \mathrm{a}$ \\
\hline \multirow[t]{2}{*}{$\mathrm{CF}$} & C-Score lowest & Prop $=0.571$ & $\mathrm{n} / \mathrm{a}$ & $\mathrm{n} / \mathrm{a}$ & $X^{2}=3.951 *$ \\
\hline & C-Score highest & Prop $=0.482$ & $\mathrm{n} / \mathrm{a}$ & $\mathrm{n} / \mathrm{a}$ & $\mathrm{p}=(0.047)$ \\
\hline \multirow[t]{2}{*}{ Audit } & C-Score lowest & Prop $=0.953$ & $\mathrm{n} / \mathrm{a}$ & $\mathrm{n} / \mathrm{a}$ & $X^{2}=15.324 * * *$ \\
\hline & C-Score highest & Prop $=0.634$ & $\mathrm{n} / \mathrm{a}$ & $\mathrm{n} / \mathrm{a}$ & $\mathrm{p}=(0.000)$ \\
\hline \multirow[t]{2}{*}{ IInst } & C-Score lowest & Mean $=0.352$ & $\mathrm{t}=-1.543$ & $\mathrm{z}=1.317$ & $\mathrm{n} / \mathrm{a}$ \\
\hline & C-Score highest & Mean $=0.288$ & $\mathrm{p}=(0.124)$ & $\mathrm{p}=(0.188)$ & $\mathrm{n} / \mathrm{a}$ \\
\hline \multirow[t]{2}{*}{ ManOnw } & C-Score lowest & Mean $=0.157$ & $\mathrm{t}=5.904 * * *$ & $z=-2.466^{* *}$ & $\mathrm{n} / \mathrm{a}$ \\
\hline & C-Score highest & Mean $=0.095$ & $\mathrm{p}=(0.000)$ & $\mathrm{p}=(0.014)$ & $\mathrm{n} / \mathrm{a}$ \\
\hline \multirow[t]{2}{*}{ Litigation } & C-Score lowest & Prop $=0.424$ & $\mathrm{n} / \mathrm{a}$ & $\mathrm{n} / \mathrm{a}$ & $X^{2}=2.540$ \\
\hline & C-Score highest & Prop $=0.531$ & $\mathrm{n} / \mathrm{a}$ & $\mathrm{n} / \mathrm{a}$ & $\mathrm{p}=(0.111)$ \\
\hline \multirow[t]{2}{*}{ Size } & C-Score lowest & Mean $=8.234$ & $\mathrm{t}=-0.840$ & $z=-0.753$ & $\mathrm{n} / \mathrm{a}$ \\
\hline & C-Score highest & Mean $=7.407$ & $\mathrm{p}=(0.020)$ & $\mathrm{p}=(0.000)$ & $\mathrm{n} / \mathrm{a}$ \\
\hline
\end{tabular}

Denote a two-tailed p-value of less than $0.10,0.05$, and 0.01 , respectively

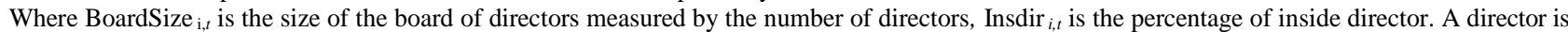
considered as inside when he exercises executive functions in the firm or in the group, IInst $t_{\mathrm{i}, \mathrm{t}}$ the participation of institutional investors in the capital, ManOnw $_{i, t}$ : is the total common shares held by managers divided by total common shares outstanding, $\mathrm{X}$ i,t is the earnings per share for firm $\mathrm{i}$ in fiscal year t, Pi,t-1 is the price per share at the beginning of the fiscal year, Rit is the return on the firm i over the period 9 months before fiscal yearend t to three months after fiscal year-end t, M/B : the market-to-book ratio, LEV: it is the total of the debts divided by market value of equity. CF i,t is a dummy variable that equals to 1 the CEO is also the chairman of the board and 0 when there is separation of the position of Chaiman of the board and the CEO or when the board have a two-tier structure supervisory board / management board, Audit i,t is a dummy variable taking the value 1 when the company in question is audited by at least one Big Four accounting firm, and 0 otherwise. Litigation i,t is a dummy variable which is equal to the 1 if the company is a high-technology company and 0 otherwise. Ln (Tot Act) = the natural logarithm of total assets.

For discrete variables, duality of the roles of CEO and board chairman (CF), the Quality audit (Audit), the hightechnology company (Litigation), the differences between proportions is based on the independent test Chi-Square.

The results show important differences between the two groups with respect to the percentage of inside director (Insdir), the size of the board (BoardSize ), managerial ownership (ManOwn), the roles of CEO and board chairman (CF), the Quality audit (Audit). However, the t-test shows that the variable "participation of institutional investors in the capital IInst" is not significant, and the test of Chi-Square shows that the variable Litigation is also not significant.

Although it is not displaying all the assumptions that we have developed previously, the univariate analysis shows that companies with a high level of conservatism have the following characteristics:

1) a small proportion of inside director serving on the board; "very likely"

2) a small board of directors; "very likely"

3) a small separation of the roles of CEO and Chairman of the board; "very likely"

4) audited by Big Four accounting firm; "very likely"

5) a small proportion of managerial ownership; "very likely"

6) no institutional control; " less likely"

7) no high-technology firms (litigation); "less likely"

8) non big size; "less likely"

\subsection{Results of multivariate tests}


Table 3 presents the results of regressions over the period 2007-2011. Model 2 was estimated by eliminating the variable C-score t-1from the model of our study (model 1). The advantage of the estimation of the model by introducing the variable $\mathrm{C}$ score delayed consists in the fact that it allows a better evaluation of the capacity of the model to explain the studied phenomenon and an appreciation of the stability of the obtained results. Because the model highlights the same significant factors with the variable $\mathrm{C}$ score delayed and without the variable $\mathrm{C}$ score delayed, we can assert that the obtained results are reliable.

Model 1: Model with delayed variable C-score

$$
\begin{aligned}
& C \text {-SCORE } i, t=a 0+a 1(C \text {-score }) i, t-1+a 2 \text { Insdiri,t }+a 3 C F i, t+a 4 \text { BoardSize } i, t+a 5 I I n s t i, t+a 6 M a n O n w i, t \\
& +a 7 \text { Audit } i, t+a 8 \text { Litigation } i, t+a 9 \text { Ln }(\text { Tot Act }) i \varepsilon i, t
\end{aligned}
$$

Model 2: Model without delayed variable C-score

$$
\begin{aligned}
& C-S C O R E i, t=a 0+a 1 \text { Insdiri,t }+a 2 C F i, t+a 3 \text { BoardSize } i, t+a 4 \text { IInsti, } t+a 5 \text { ManOnw i,t }+a 6 \text { Audit } i, t+a 7 \\
& \text { Litigation } i, t+a 9 \operatorname{Ln}(\text { Tot Act }) i+\varepsilon i, t
\end{aligned}
$$

In Table 4 the first (second) estimation considers all restatements, and excludes (includes) firm fixed effects.

The coefficient on Insdir is negative and significant at $1 \%$ level in the two columns of table 3 consistent with the level of independence of the board from management has a significant influence on accounting conservatism. This means that as the ratio of inside directors is low, the board is more independent from the management and thus financial statements

\begin{tabular}{|c|c|c|c|c|c|c|c|c|}
\hline Variables & Expectedsign & Model (1) & Model 1.1 & Model 1.2 & Model 1.3 & Model 1.4 & Model .5 & Model .6 \\
\hline Constant & & $\begin{array}{l}0.752 \\
(1.122)\end{array}$ & $\begin{array}{l}0.635 \\
(1.369)\end{array}$ & $\begin{array}{l}0.352 \\
(4.058) * * *\end{array}$ & $\begin{array}{l}0.984 \\
(4.696) * * *\end{array}$ & $\begin{array}{l}0.814 \\
(6.510) * * *\end{array}$ & $\begin{array}{l}0.252 \\
(1.268)\end{array}$ & $\begin{array}{l}0.427 \\
(5.179) \\
* * *\end{array}$ \\
\hline C-score ${ }_{i, t-1}$ & $+/-$ & $\begin{array}{l}0.897 \\
(5.398) * * *\end{array}$ & $\begin{array}{l}0.933 \\
(4.869) * * *\end{array}$ & $\begin{array}{l}0.856 \\
(4.257) * * *\end{array}$ & $\begin{array}{l}0.358 \\
(5.869) * * *\end{array}$ & $\begin{array}{l}0.652 \\
(4.257) * * *\end{array}$ & $\begin{array}{l}0.474 \\
(3.854) \\
* * *\end{array}$ & $\begin{array}{l}0.967 \\
(3.257) \\
* * *\end{array}$ \\
\hline Insdir & $+/-$ & $\begin{array}{l}-0.129 \\
(-5.080) * * *\end{array}$ & & $\begin{array}{l}-0.587 \\
(-5.147) * * *\end{array}$ & & & & \\
\hline $\mathrm{CF}$ & $+/-$ & $\begin{array}{l}0.238 \\
(5.156) * * *\end{array}$ & & & $\begin{array}{l}0.254 \\
(4.874) * * *\end{array}$ & & & \\
\hline BoardSize & $+/-$ & $\begin{array}{l}-0.096 \\
(-5.634) * * *\end{array}$ & & & & $\begin{array}{l}-0.631 \\
(-4.472) * * *\end{array}$ & & \\
\hline IInst & $+/-$ & $\begin{array}{l}-0.351 \\
(-0.857)\end{array}$ & & & & & $\begin{array}{l}-0.535 \\
(-1.198)\end{array}$ & \\
\hline ManOnw & $+/-$ & $\begin{array}{l}-0.481 \\
(-2.944) *\end{array}$ & & & & & & $\begin{array}{l}-0.976 \\
(-4.864) \\
* * *\end{array}$ \\
\hline Audit & $+/-$ & $\begin{array}{l}(-0.646) \\
(-1.952) *\end{array}$ & $\begin{array}{l}-0.224 \\
(-4.734) * * *\end{array}$ & $\begin{array}{l}-0.967 \\
(-4.876) * * *\end{array}$ & $\begin{array}{l}-0.828 \\
(-4.953) * * *\end{array}$ & $\begin{array}{l}-0.567 \\
(-3.218) * * *\end{array}$ & $\begin{array}{l}-0.727 \\
(-2.963) * *\end{array}$ & $\begin{array}{l}-0.291 \\
(-1.494)\end{array}$ \\
\hline Litigation & $+/-$ & $\begin{array}{l}-0.181 \\
(-1.253)\end{array}$ & $\begin{array}{l}-0.366 \\
(-0.969)\end{array}$ & $\begin{array}{l}0.874 \\
(0.566)\end{array}$ & $\begin{array}{l}-0.321 \\
(-0.479)\end{array}$ & $\begin{array}{l}0.852 \\
(1.137)\end{array}$ & $\begin{array}{l}-0.472 \\
(-0.428)\end{array}$ & $\begin{array}{l}0.892 \\
(0.655)\end{array}$ \\
\hline $\operatorname{Ln}($ Tot Act $)$ & $+/-$ & $\begin{array}{l}-0.181 \\
(-0.983)\end{array}$ & $\begin{array}{l}0.694 \\
(0.359)\end{array}$ & $\begin{array}{l}0.967 \\
(1.096)\end{array}$ & $\begin{array}{l}1.895 \\
(4.527) * * *\end{array}$ & $\begin{array}{l}0.478 \\
(0.752)\end{array}$ & $\begin{array}{l}0.967 \\
(0.284)\end{array}$ & $\begin{array}{l}-0.982 \\
(-1.087)\end{array}$ \\
\hline $\operatorname{Adj} R^{2}$ & & $30.10 \%$ & $13.90 \%$ & $14.80 \%$ & $20.40 \%$ & $12.20 \%$ & $6.50 \%$ & $9.90 . \%$ \\
\hline Statistique F & & $11.933 * * *$ & $8.644 * * *$ & $9.927 * * *$ & $13.857 * * *$ & $8.344 * * *$ & $6.638 * * *$ & $7.984 * * *$ \\
\hline
\end{tabular}
are prepared with more conservatism. Our results support the finding of [1] [5] and [2] on a sample of American companies. This finding is consistent with several previous researches. The percentage of inside directors on the board is negatively related with other variables (fraud at the financial reports, proxy management results).

Where C-score i, t-1 is the level of conservatism of the previous year, Admint i,t is the percentage of inside director. A director is considered as inside when he exercises executive functions in the firm or in the group, CF i,t is a dummy variable that equals to 1 if the CEO is also the chairman of the board and 0 when there is separation of the position between Chairman of the board and the CEO or when the board have a two-tier structure supervisory board / management board, TC i,t is the size of the board of directors is measured by the number of directors, Ilnst i,t the participation of institutional investors in the capital, PropMAN i,t: is the total common shares held by managers divided by total common shares outstanding, Audit $\mathrm{i}, \mathrm{t}$ is a dummy variable taking the value 1 when the company in question is audited by at least one Big Four firms, and 0 otherwise. Litigationi,t : is a dummy variable which is equal to 1 if the company is a high-technology company and 0 otherwise.

$* * *, * * *$, respectively meaning $10 \%, 5 \%$ and $1 \%$

Figures in brackets indicate t of Student 
Table 5: Model2 without delayed variable C-score

\begin{tabular}{|c|c|c|c|c|c|c|c|}
\hline Variables & Expected Sign & Model (2) & Model (2.1) & Model (2.2) & Model (2.3) & Model (2.4) & Model (2.5) \\
\hline Constant & & $\begin{array}{l}0.6354 \\
(0.136)\end{array}$ & $\begin{array}{l}0.933 \\
(4.869) * * *\end{array}$ & $\begin{array}{l}0.852 \\
(4.797) * * *\end{array}$ & $\begin{array}{l}0.967 \\
(4.657) * * *\end{array}$ & $\begin{array}{l}0.863 \\
(4.073) * * *\end{array}$ & $\begin{array}{l}1.265 \\
(5.144) * * *\end{array}$ \\
\hline Insdir & $+/-$ & $\begin{array}{l}-0.369 \\
(-6.682) * * *\end{array}$ & $\begin{array}{l}-0.224 \\
(-4.734) * * *\end{array}$ & & & & \\
\hline $\mathrm{CF}$ & $+/-$ & $\begin{array}{l}0.475 \\
(5.282) * * *\end{array}$ & & $\begin{array}{l}0.634 \\
(5.263) * * *\end{array}$ & & & \\
\hline BoardSize & $+/-$ & $\begin{array}{l}-0.082 \\
(-5.091) * * *\end{array}$ & & & $\begin{array}{l}-0.092 \\
(-4.027) * * *\end{array}$ & & \\
\hline IInst & $+/-$ & $\begin{array}{l}0.268 \\
(0.625)\end{array}$ & & & & $\begin{array}{l}-0.848 \\
(-0.733)\end{array}$ & \\
\hline ManOnw & $+/-$ & $\begin{array}{l}-0.358 \\
(-3.201) * * *\end{array}$ & & & & & $\begin{array}{l}-0.333 \\
(-4.892) * * *\end{array}$ \\
\hline Audit & $+/-$ & $\begin{array}{r}0.646 \\
(2.248)^{*}\end{array}$ & $\begin{array}{l}0.721 \\
(3.721) * * *\end{array}$ & $\begin{array}{l}1.371 \\
(4.962) * * *\end{array}$ & $\begin{array}{l}2.492 \\
(4.884) * * *\end{array}$ & $\begin{array}{l}1.267 \\
(5.879) * * *\end{array}$ & $\begin{array}{l}-.591 \\
(5.420) * * *\end{array}$ \\
\hline Litigation & $+/-$ & $\begin{array}{l}0.181 \\
(1.253)\end{array}$ & $\begin{array}{l}-0.366 \\
(0.969)\end{array}$ & $\begin{array}{l}0.214 \\
(0.427)\end{array}$ & $\begin{array}{l}-0.236 \\
(-1.137)\end{array}$ & $\begin{array}{l}-0.128 \\
(-1.108)\end{array}$ & $\begin{array}{l}-0.212 \\
(-0.851)\end{array}$ \\
\hline $\operatorname{Ln}($ Tot Act $)$ & $+/-$ & $\begin{array}{l}0.181 \\
(0.983)\end{array}$ & $\begin{array}{l}0.694 \\
(0.359)\end{array}$ & $\begin{array}{l}0.637 \\
(1.369)\end{array}$ & $\begin{array}{l}0.985 \\
(1.253)\end{array}$ & $\begin{array}{l}0.963 \\
(1.403)\end{array}$ & $\begin{array}{l}0.584 \\
(-0.879)\end{array}$ \\
\hline $\operatorname{Adj} \mathrm{R}^{2}$ & & $24.10 \%$ & $14.20 \%$ & $15.4 \%$ & $17.90 \%$ & $10.90 \%$ & $18.20 \%$ \\
\hline Statistique F & & $10.975 * * *$ & $11.396 * * *$ & $12.416 * * *$ & $14.655 * * *$ & $8.760 * * *$ & $15.751 * * *$ \\
\hline
\end{tabular}

Where C-score i, t-1 is the level of conservatism of the previous year, Admint i,t is the percentage of inside director. A director is considered as inside when he exercises executive functions in the firm or in the group, CF i,t is a dummy variable that equals to 1 if the CEO is also the chairman of the board and 0 when there is separation of the position between Chairman of the board and the CEO or when the board have a two-tier structure supervisory board / management board, TC i,t is the size of the board of directors is measured by the number of directors, IInst i,t the participation of institutional investors in the capital, PropMAN i,t: is the total common shares held by managers divided by total common shares outstanding, Audit $\mathrm{i}, \mathrm{t}$ is a dummy variable taking the value 1 when the company in question is audited by at least one Big Four firms, and 0 otherwise. Litigationi,t : is a dummy variable which is equal to 1 if the company is a high-technology company and 0 otherwise.

$* * *, * * *$, respectively meaning $10 \%, 5 \%$ and $1 \%$

Figures in brackets indicate t of Student.

[46] found a negative relationship between the percentage of inside directors and some evidence of earnings management" the percentage of internal directors on the board is negatively associated with fraud in the financial reports". These studies argue that board independence is negatively associated positively with accounting conservatism. The tests confirm the effect of the size of the board of directors on accounting conservatism. The coefficient of size of the board is negative and significant at $1 \%$ level which confirms our predictions. [23] argues that large boards are less effective than small boards due to the difficulties of coordinating and engaging a large group. Larger boards can also suffer from the 'free-rider' problem in the sense that each board member relies on the other members to monitor management. Consequently, large boards of directors consisted of a high number of directors are less effective and are not strong enough to require higher level of conservatism in financial statements produced. This may oppose the following reasoning: the large size encourages directors to specialize, [30] showed that the independence of the audit committee is positively related to the size of the board, and that specialization can lead to more effective control. Similarly, [13] found that companies take advantage of having large boards.

The coefficient of management ownership "Manown"is negative and significant at $5 \%$ and $1 \%$ levels. This means that as the participation of managers grows the risk of their entrenchment grows, managers may act in their own interest and supply financial information produced with low level of conservatism. These results are different from those of [1] which found a positive but not significant relationship. This can be explained by the difference of ownership structures. Indeed, the French ownership structure is more concentrated than the American. In this respect we state that the agency problems lead to a request from the accounting conservatism as a regulator of the opportunistic behavior of managers. Similarly, [31] [32] suggest that managerial ownership is negatively associated with accounting conservatism even after controlling the effect of informational asymmetry. This result may be consistent with the logic of [23]. Indeed, when the accounting conservatism is insufficient, the relationship between conservatism and earnings information asymmetry is significantly negative. Conversely, when accounting profit is much more conservative, influence on the asymmetry of information is positive.

However, we do not find a significant effect of institutional ownership on accounting conservatism in France. Indeed, [42] stated that the presence of institutional investors is negatively associated with accounting conservatism. The empirical study of [42] showed that long-term institutional investors are not significantly correlated with accounting conservatism. The divergence of views do not predict their effects on the application of the precautionary principle in France.

We note that the effect of audit quality is significant at $10 \%$ level only in model 2. [29] showed that the "Big Four" are differentiated from other firms by their conservative attitudes vis-à-vis accounting choices. Therefore, seeking a quality, 
large firms tend to "restrain" the opportunistic behavior of managers and to be more conservative than other firms. Indeed, [9] reported that after the Enron scandal and the involvement of Arthur Anderson auditors have become more conservative.

As shown by [1] the effect of the separation of the functions of CEO and chairman of the board is unrelated to accounting conservatism. It is in this sense that [10] showed that the management board is jeopardized when the CEO also serves as chairman of the board. In fact, a CEO who is also the chairman of the board has more power and therefore greater managerial discretion in the application of accounting principles including the pricinciple of accounting conservatism.

The two control variables, ln (Size) and litigation are not important determinants of accounting conservatism. The postive and insignificant coefficients on the proxy for the firm size imply that large entreprtises do not limit the scope of accounting conservatism. This suggests that large companies do not generally have better internal control systems. It may also be noted that a negative and not significant relationship between the risk of legal disputes and accounting conservatism. The empirical invalidation of this relationship may be explained by the fact that companies with a risky business in judicial matters (high Tech) does not necessarily limit the use of accounting conservatim because of the high risk of litigation initiated by shareholders

\section{$5 \quad$ Summary and conclusion}

The objective pursued throughout our study was to show that when corporate governance mechanisms function well, the level of accounting conservatism is high. Various mechanisms of corporate governance were presented in the literature as having an efficient influence on the quality of financial statements and accounting conservatism such as the presence of independent directors, the size of the board, separation of functions of CEO and chairman of the board or being audited by Big Four firms. Our results show that the size of the board, the board independence and the management ownership explain the level of accounting conservatism. Indeed, the most conservative companies are companies which have boards of directors of low size, which are more independent of the management and in which the participation of the management is low. The results of our study are consistent with former studies on accounting conservatism [14] [1] [33]. We confirm a general upward trend in the degree of conservatism in financial statements published by French companies during the period 2007-2011. The analyses of [14] highlight improvement in the conservatism aspect of accounting earnings published by French listed companies during the 1990s.

Our results have important implication for accounting standards setters and securities acts whose main objective is reducing information asymmetry in equity markets. [31] find that accounting conservatism increases with accounting information asymmetry and explain that equity investors demand more conservative earnings as a means of mitigating agency problems. They highlight that users value the verifiability of accounting information as accounting provide hard verifiable benchmark useful in mitigating information asymmetries. We find that higher level of accounting conservatism is explained by efficient mechanisms of corporate governance. Thus, to achieve reducing information asymmetry, efficient governance mechanisms should be implemented.

Other external factors to the company, such as the legal environment, the stock-exchange laws and the economic policy of the country as well as the culture of the actors determine in a significant way the level of the conservatism [8] [44] [45] were not studied within this research. It will be interesting to study on a sample of companies belonging to several countries the relationship between accounting conservatism and institutional and economic factors as well as the structures of corporate governance

\section{References}

[1] Ahmed A. and Duellman S. (2007). Accounting conservatism and board of director characteristics: an empirical analysis. Journal of Accounting and Economics, 43, pp 411-437.

[2] Ahmed, A., and. Duellman S. (2013). Managerial overconfidence and accounting conservatism. Journal of Accounting Research, vol $51 \mathrm{n}^{\circ} 1$.

[3] Ahmed, K. and Henry, D., (2011). Accounting conservatism and voluntary corporate governance mechanisms by Australian firms. Accounting and Finance, 51: 1-32.

[4] Basu, S. (1997). The conservatism principle and the asymmetric timeliness of earnings. Journal of Accounting And Economics, vol 24, pp337 ,

[5] Beekes W., Pope P. and Young S. (2004). The link between earnings timeliness, earnings conservatism and board composition: evidence from the UK. Corporate Governance : An International Review,

[6] Belkaoui A. (1985), Accounting theory. 2nd edition, Harcourt Brace Jovanovich, Orlando, Florida.

[7] Bessieux-Ollier C. (2006). Les pratiques d'évaluation et de publication des entreprises françaises, allemandes et américaines : Le cas des éléments incorporels. Comptabilité Contrôle, Audit, 13, 219-246.

[8] Bushman R. and Piotroski J. (2006). Financial Reporting Incentives For Conservative Accounting: The Influence Of Legal And Political Institutions, Journal of Accounting and Economics, vol 42, pp 107-148,

[9] Cahan. S. and W. Zhang. (2006). After Enron auditor conservatism and ex-Andersen clients. The Accounting Review 8: pp 49-82. 
[10] Cheng, S., (2008). Board size and the voriability of corporate performance. Journal of Financial Economics vol87, ${ }^{\circ} 1$, pp 57-176.

[11] Choi, J., and T. Wong J. (2007), Auditors Governance Functions and Legal Environments: An International Investigation. Contemporary Accounting Research. vol24 (1), pp13-46,

[12] Chtourou S.M, Bédard J. and Courteau L. (2001), corporate governance and earnings management, www.ssrn.com.

[13] Coles, J., Daniel, N., Naveen, L., (2008). Boards: does one size fit all? Journal of Financial Economics, vol 87, pp 329-356.

[14] Ding Y. and Stolowy H. (2006). Timelness and conservatism: Changes over times in the properties of accounting in France. Review of Accounting And Finance, vol 5 (2)., pp 92-107.

[15] Fan, J. P. H., and T. J. Wong (2005). Do external auditors perform a corporate governance role in emerging markets: Evidence from East Asia? Journal of Accounting Research, 43 (1), pp35-72.

[16] Feltham, G. and Ohlson, J. A. (1995). Valuation and clean surplus accounting for operatingand financial activities. Contemporary Accounting Research, 11, pp 689-731

[17] Field L., Lowry M., and Shu S., (2005). Does Disclosure Deter or Trigger Litigation?, Journal of Accounting and Economics, 39, pp 487-507

[18] Gao, P. (2013). A measurement approach to conservatism and earnings management. Journal of Accounting and Economics, vol 55n ${ }^{\circ}$, pp251.268.

[19] Gao, Y., and A. Wagenhofer. (2012). Accounting conservatism and board efficiency. Working paper, City University of Hong Kong and University of Graz

[20] Givoly D, Hayn C. and Natarajan (2007). Measuring Reporting Conservatism. The Accounting Review, 82 (1), pp 65-106,

[21] Givoly, D., and Hayn, C. (2000). The Changing Time-Series Properties Of Earnings, Cash Flows and Accruals: Has Financial Reporting Become More Conservative? Journal of Accounting And Economics, 29, pp 287-320

[22] Guay, W. (2008). Conservative financial reporting, debt covenants, and the agency costs of debt. Journal of Accounting and Economics, vol $45(2 / 3)$, pp175-180,

[23] Jensen, M.C. (1993). The modern industrial revolution, exit and failure of internal control systems. Journal of Finance, 48, 831-880.

[24] Jiambalvo J., S. Rajgopal, and. Venkatachalam M. (2002). Institutional ownership and the extent to which stock prices reflect future earnings. Contemporary Accounting Research, 19, pp 177-145,

[25] John, K., Senbet, L., (1998). 'Corporate governance and board effectiveness'. Journal of Banking and Finance, vol 22, pp $371-403$.

[26] Johnson, J., Daily, C., Ellstrand, A., (1996). « Board of directors: a review and research agenda ». Journal of Management, vol 22, pp 409438 .

[27] Juo-Lien Wang (2013) Accounting Conservatism and Information Asymmetry: Evidence from Taiwan, International Business Research; Vol. $6, \mathrm{n}^{\circ} .7 ; \mathrm{pp} 32-43$

[28] Khan, M., and. Watts R. L. (2009). Estimation and validation of a firm-Year Measure of Conservatism. Journal of Accounting \& Economics, $48(2 / 3)$, pp132-150,

[29] Kim, J.B., Chung, R. and Firth, M. (2003), “Auditor conservatism, asymmetric monitoring and earnings management", Contemporary Accounting Research, Vol.20 (2):pp.323-359.

[30] Klein, A. (2002). Audit committee, board of director characteristics, and earnings management. Journal of Accounting And Economics, 33, pp375-400,

[31] Lafond, W and Watts R.L (2008). The information role of conservatism. The Accounting Review, 83(2) 447-478, doi: 10.2308/accr.2008.83.2.447,

[32] Lafond, W., and Roychowdhury S. (2008). Managerial Ownership and Accounting Conservatism, Journal of Accounting Research, 83(2)., pp447-478,

[33] Lara J., Osma B., and Penalva F (2007). Board of directors' characteristics and conditional accounting conservatism: Spanish evidence. European Accounting Review, 16 (4), pp727-755,

[34] Lara, J. M., \& Mora, A. (2004). Balance Sheet versus Earnings Conservatism. European Accounting Review, Vol. 13, n . 2, pp 261-292.

[35] Lasteyrie J.C (2002), Capitalisme et marchés financiers: Une crise de confiance, CCIP, 20 Pages.

[36] Lin, J. W., \& Hwang, M. I., (2010). Audit Quality, Corporate Governance, and Earnings Management: A Meta-Analysis, International Journal of Auditing, vol14, pp 57-77.

[37] Lobo G., and Zhou J. (2006). Did conservatism in financial reporting increase after the Sarbanes-Oxley Act? Initial evidence”. Accounting Horizons, 20(1)., pp57-73,

[38] Lorsch J.and MacIver E., (1989). Pawns or potentates: The reality of America's corporate boards, Harvard Business School Press.

[39] Lu, X and Trabelsi S, (2013), Information Asymmetry and Accounting Conservatism under IFRS Adoption. CAAA Annual Conference 2013. Available at SSRN:http://ssrn.com/abstract=2201206 or http://dx.doi.org/10.2139/ssrn.2201206

[40] Nikolaev, V. V. (2010). Debt Covenants and Accounting Conservatism. Journal of Accounting Research, Vol. 48 No. 1, pp137-176,

[41] O'Sullivan N. (2000). The determinants of non-executive representation on the boards of large UK companies. Journal of Management and Governance, vol 4, pp 283-297.

[42] Ramalingegowda, S., and Y. Yu. 2012. Institutional ownership and conservatism. Journal of Accounting and Economics, vol53 (1-2), pp 98114.

[43] Roychowdhury, S., and. Watts R. L. (2007). Asymmetric timeliness of earnings, market-to-book and conservatism in financial reporting. Journal of Accounting and Economics, vol 44, pp 2-31.

[44] Watts R. (2003a), Conservatism in accounting, Part I: explanations and implications, Accounting Horizons, vol 17(3), pp 207-221

[45] Watts R. (2003b). Conservatism in accounting Part II: evidence and research opportunities, Accounting Horizons, vol 17(4), $287-301$.

[46] Xie, B., W. N. Davidson, and P. DaDalt. 2003. Earnings management and corporate governance: the role of the board and the audit committee. Journal of Corporate Finance 9: 295-316.

[47] Yeoh E. and Jubb C.A., (2001). Governance and audit quality: is there an association?", Working Paper, University of melbourne, Australia.

[48] Zhang, J. (2008). The contracting benefits of accounting conservatism to lenders and borrowers. Journal of Accounting and Economics, vol 45 , pp $27-54$. 